\title{
Integration of Play, Learning, and Experience: What Museums Afford Young Visitors
}

\author{
Tara Zollinger Henderson · David J. Atencio
}

Published online: 11 September 2007

(C) Springer Science+Business Media, LLC 2007

\begin{abstract}
This paper examines important factors in maximizing children's experiential learning in the context of inquiry-based children's museums. Learning is understood as situated in physical, social, and interactive context that is best achieved when children have opportunities to engage in play-based inquiry. Recommendations for maximizing children's learning in museums, supporting children's interactions with peers and adults, and offering affordances for children's play are discussed.
\end{abstract}

Keywords Museums · Inquiry-based learning · Play $\cdot$ Experiential learning $\cdot$ Learning $\cdot$ Experience

Across children's development, there are many ways that learning is experienced. In certain situations and at certain levels, learning is the process of understanding that occurs through children's perception, encoding, and subsequent retrieval of information that modifies their future behaviors and attitudes. In other situations, learning is essentially the outcome of children's observation of someone's actions and their subsequent attempts to replicate the observed actions. As Dewey (1938) argued long ago, conventional views of learning focus on acquiring knowledge that is contained in books or in the minds of elders. Possessing this simplistic concept of learning is particularly problematic for early childhood professionals because it causes us to see young children as passive, receptive, and absorbing in their acquisition of knowledge. Whether early

T. Z. Henderson · D. J. Atencio $(\square)$

Department of Individual, Family and Community Education,

The University of New Mexico, Simpson Hall, MSC 05 3040, Albuquerque, NM 87131, USA

e-mail: atencio1@unm.edu childhood professionals are preparing lessons within their classrooms or developing plans for field trips in the community, the conceptualizations of children's learning and the opportunities afforded to them are determined in part by the notions teachers have about learning. Henschel (1999, Unpublished manuscript) provides a wonderful conceptual framework for anchoring our understanding of this concept by postulating seven principles of learning.

First, learning is fundamentally social. Children are constantly embedded in a social milieu that affords them opportunities for dialogue with others, observation of others, opportunities for inquiry, and opportunities for reflection with others. Second, knowledge is integrated in the life of communities. As children develop, share values, perspectives and ways of doing things, they create a community of practice. Third, learning is an act of participation. Children are motivated to learn by their desire to participate in the community of practice. Children's learning is a product of joint socialization between themselves and those around them. Fourth, knowing depends on engagement in practice. Children gain understanding from their observations of, participation in, and reflection of a variety of social activities and activities that derive from their physical interactions with objects. Fifth, engagement is inseparable from empowerment. Children construct their understanding of themselves, in part, by the contributions they make to the collective activity in which they are engaged. Sixth, failure to learn is the direct result of being excluded from participating. Children need to be afforded access and opportunity in order for them to contribute and in order for them to gain knowledge and interest from such participation. Seventh, learning is a lifelong process and is a natural part of human nature. Children's tendency to learn is a natural process that unfolds whenever children are afforded opportunities for engagement, interaction, and discovery. 
For early childhood professionals, learning is best viewed as an authentic and natural component of children's activity and as the experience derived from their engagement in activity. In Situativity Theory (Greeno and Moore 1993), children's learning is understood as interactions amongst children-as-agents-in-their-own-thinking, physical systems, and other people. Much like cognitive and affective processes in development are synergistic (Sorrentino and Higgins 1986), the activity that unfolds as a product of children acting in their environments can be understood as a synergism of experience, learning, and play. Clearly, children's learning is a product of their social experiences with their peers, siblings, parents, teachers, caregivers and other individuals that constitute their social experience. Social influences on children's learning are indeed varied and complex in development (Azmitia and Perlmutter 1989). However, children's gradual development of abilities also depends on their interactions with physical objects and symbols in their learning environments. Within the Bioecological model of development (Bronfenbrenner and Ceci 1994), children's learning is understood as an outcome of what is called proximal processes. Proximal processes are understood as the engines that drive development over time and that vary systematically as a joint function of genetic potentials in individuals and the environmental contexts in which development occurs (Bronfenbrenner 1995; Bronfenbrenner and Ceci 1994; Bronfenbrenner and Morris 1998). In particular, proximal processes account for transactions between developing individuals and the persons, objects, symbols, and activities that comprise one's Microsystems (Bronfenbrenner 2001). Therefore, it is impossible to consider learning, ability, or intelligence characteristics as solely attributed to individuals. Such cognitive phenomena are inherently contextualized, socially interactive, and embedded in physical, social, and interactive experiences. In the context of early education, there exists no other physical, social and interactive experience as influential to children's development as play.

\section{Play As A Situative Affordance for Learning}

What happens when learning becomes synonymous with play and experience? What environmental features afford opportunities for exploration and play? What role does intrinsic motivation play in relation to exploration, learning, and the development of competence? Questions such as these are relevant for determining contexts that best afford children with developmentally appropriate and significant learning experiences. In what has been called informal learning (Cross 2006), experiential learning (Kolb 1984), discovery learning (Bruner 1960), or self-directed learning
(Deci and Ryan 1982), play-based inquiry is understood as a fundamental mediator of children's learning as they engage in their activity. Play is a key manifestation of Bronfenbrenner's notion of proximal processes and is also consistent with the key characteristics that Henschel (1999, Unpublished manuscript) identifies in learning.

Play is children's work. According to Vygotsky (1966), it is through play that children learn to act and think in the cognitive realm instead of the behavioral or external realm that occupied their recent past. In play activity, children transcend the immediacy of the present and physical reality and explore new realms cultivated by the power of their imagination. Play is a means by which children function in their zone of proximal development (Vygotsky 1978). Within their zone, they are able to self-scaffold their engagement to more elaborate and complex levels. Play allows children to try behaviors, thoughts, experiences, roles, and skills out at a level above their normal cognitive level and in a safe arena (Pellegrini and Boyd 1993). Thus, Vygotsky viewed play as being the highest level of development for a pre-school child. Play, therefore, mediates sociocultural influences on children's development of mental functions such as human consciousness and will (Vygotsky 1987).

Piaget (1951) also viewed play as a learning process where children acquired new skills. However, Piaget's focus was on understanding why children's play became symbolic instead of remaining a plain sensory motor exercise. Piaget (1951) argued that, "symbolic play is merely egocentric thought in its pure state" (p. 567), that is, play is the manifestation of "pure" assimilation. For Piaget, play is important because it provides children with a live, dynamic, individual language that is important for the expression of their subjective feelings. Calabrese (2003) believes that symbolic or sociodramatic play mediates young children's social, emotional, physical, and cognitive development.

Play affords cogntive challenge; play allows children to develop creativity, problem-solving, logic, social knowledge, and language (Christie and Johnson 1983). Play is also a mechanism of social development. Collective play essentially builds social competence and generally leads to favorable social development (Stams et al. 2002). Play, in many ways, optimizes young children's development. It is important, therefore, that young children's formal and informal learning environments encourage, rather than inhibit play.

\section{Environments for Play and Learning}

Environments can support and encourage play or they can stifle play. Dempsey and Frost (1993) argue that it is not 
only the environment inside the classroom but also the environment outside of the classroom that influences play and its enhancement of children's development. Examples of factors that influence the environment and likewise children's play are the number of students in a given classroom and the child to adult ratio, the materials provided, the arrangement of the classroom, the children's ages, sex stereotyped toys, the culture and nationality of the students and educators, the socioeconomic status of the children, and the location of the play environment (e.g. outside versus inside). While all of these factors create the unique environments in which children play and learn, it is important to remember that the "emphasis [should be] on the process of learning, with adults supporting children's learning" (Rogoff et al. 1998, p. 402). This means that learning is an ongoing dynamic process and not simply a static consequence of experience. Students' learning should be activity-based and derive from experiences with integrated curricula that accommodate individual differences in learning styles, interests, and prior experiences. If children possess interests in specific areas, they are more apt to engage themselves at a deeper level and subsequently acquire more in-depth knowledge about particular content areas than when no interest exists for a particular content area. For young children, learning derived from one's interests is something that is enjoyable and is eagerly pursued, rather than being a tedious task to avoid. In addition, every individual is both a student and a teacher. Children learn from adults, from other children, and by exploring on their own. Adults learn from children, from other adults, and by their own experiences and exploration. Within a museum context, learning is embedded in the interactive processes between participants and with the media at hand. Museum learning is, therefore, dialogical as well as hands-on.

The emphasis then is on the experience that is had within the environment. Experiences that lead to growth are what are important, according to Dewey (1938). It then is the educators' job to shape and support the environment so that it is conducive to experiences that lead to growth. Thus it is the quality of the experience, not just the experience itself, that is important. For an individual teaching a class, giving a lecture, or designing exhibits, the important question to ask is "how did this experience contribute to what someone knows, feels, or understands?" (Lundmark 2002 , p. 235). It is not about what an individual learns but how that experience contributes to the prior experiences of the individual.

To create environments that are conducive to quality experiences, exploration, and play, it is important that individuals in the environment are encouraged to act on, explore, manipulate, sort, and describe the phenomenon they are investigating (Harlen 2001). There must be opportunities afforded for individuals to physically interact with the environment and solve the problems posed (Speaker 2001). These opportunities to interact with the environment should occur in a variety of different ways (e.g. visual, perceptual, kinesthetic, and effective problem solving strategies). Along with incorporating many different ways to interact with the environment, it is also important that the environment integrates different aspects of life together with different areas of curriculum. The context cannot be separated from the cognitive development that occurs when individuals interact, explore, manipulate, and play with aspects of their environment. According to Cole (1995), the contexts in which cognitive development occur are woven together with each other and with the surrounding environments.

It is important, then, when creating an environment in which to encourage play that the emphasis is on the experience and the learning process. It is also important to keep in mind that the context of play is not simply the physical situation, classroom curriculum, availability or absence of toys, or the children that are present, but rather, the context of play is an amalgam of all of these (Malone 1999). It is equally important to keep in mind the power that situations have on children's learning and the important principles of learning discussed above. One such environment that strives to accomplish this is that of inquiry-based children's museums.

\section{Museums as Environments for Learning}

The statement "a museum is an educational country fair" (Semper 1990, p. 50) conjures up images of a place full of exciting things to be explored and discovered, a place where individuals touch, ask questions, and direct their own learning. According to Semper (1990), museums teach individuals to play because play is the basis of exploration, observations, discovery, and experimentation. Museums afford unique opportunities for individuals to explore concepts in math, science, art, and social science (McLeod and Kilpatrick 2000). Furthermore, museums can be contexts of informal learning for science. Both teachers and children engage in autonomous, yet structured, learning that is fueled by interest and choice (Ramey-Gassert 1997). Activities that promote the perception of choice and contexts that afford learnerst the opportunity to pursue their interests enhance intrinsic motivation to learn (Deci and Ryan 1985, 2000).

Inquiry based museums appeal both to children with exceptional learning needs and those without. Rapp (2005) found that within an inquiry-based museum setting, children classified as having a disability could not be distinguished by their behavior from children not classified 
as having a disability. There were several reasons why students with exceptional learning needs exhibited behavior no different than their peers in an inquiry based environment. Rapp attributed these differences to the scaffolded instruction that occurred, the meaningful and contextualized activities, the self-regulation of learning, and the establishment of a learning community. All these factors converged to create an environment where children with and without exceptional learning needs could interact in a meaningful manner and where exceptionalities disappeared.

Children's museums and, more specifically, children's science museums are valuable resources for supporting inclusion, teacher development, and field trips. Museums of this type strive to promote inquiry-based learning opportunities (McLeod and Kilpatrick 2000) and employ open-ended and person-centered questions that invite children to ask questions (Harlen 2001). It is through a partnership where schools and museums work together to combine the benefits of both the museum environment and the classroom setting that optimal learning experiences can be afforded to children. Inquiry-based museums are not a replacement to the traditional school but rather a supplement to it (Rapp 2005). Such museums provide teachers with a means to extend children's learning beyond what occurs in the classroom and provides teachers with many opportunities to engage children in collaborative, dialogical, and self-directed explorations that are a core feature of play-based learning.

It is important to keep in mind that museum experiences should be an integral part of the classroom and intertwined with children's natural learning experiences as participants in a classroom rather than a special or extra activity. Museums afford individuals the opportunity to be in control of their learning and support their autonomous, self-directed learning. Museums also provide opportunities to try out and discover new phenomena in ways that traditional classrooms have a hard time implementing (Lemelin and Bencze 2004). Instead of trying to implement what is inherent to museums, teachers should combine the formal environment of the classroom with the informal environment and abundance of information found in museums (Rapp 2005). In order to maximize the benefits from partnerships between schools and museums, teachers are encouraged to visit the museum in preparation of scheduling a field trip for their students (Rapp 2005; Martin and Seevers 2003). The questions found on Table 1 can be addressed when teachers visit the museum prior (see Table 1). We believe these are essential for teachers to be able intertwine their students' learning experiences in the classroom with their museum experience. It is also important that children are prepared for their subsequent visit to the museum (Rapp 2005; Martin and Seevers 2003). Table 2 lists some questions to address for helping children prepare for their musuem visit (see Table 2). While it is important that there is a correspondence between the curriculum in the classroom and the programs offered in the museum (Xanthoudaki 1998), the field trip to the museum should be experience-driven rather than information-driven (Rapp 2005). Secondly, teachers are encouraged to engage students in subsequent follow-up activities and in planning additional follow-up trips to the same museum (Rapp 2005). It is important to understand that the exhibits in a given inquiry-based children's museum do not have to change for children to gain new meaningful insights. Follow-up visits build upon and lead to new learning experiences that result in new-found knowledge. Direct experiences within an inquiry-based museum have been

Table 1 Questions teachers can ask prior to the museum visit

\footnotetext{
1. What is the physical layout of the museum?

2. Can information about the museum be sent to me prior to our visit?

3. What are rules that need to be followed when visiting the musuem?

4. What areas of the museum are age-appropriate for my class?

5. What exhibit areas will the students be visiting?

6. Are classes offered that provide more in-depth experience with a science phenomenon?

7. Are classes offered that provide more in-depth experience with technology?

8. Are classes offered that provide more in-depth experience with music?

9. Are classes offered that provide more in-depth experience with art?

10. Are resources available for making classroom connections \& extensions?

11. Are there time or other restrictions placed on group/class visitors?

12. Will there be a museum staff member guiding the students' visit?

13. Will there be a place indoors or outdoors for our class to have a lunch break?

14. How can I prearrange my classroom's visit so that learning is optimized?

15. Do children need to be arranged in groups for certain interactive exhibits?
} 
Table 2 Questions teachers can address to prepare students for their museum visit

1. Who will be learning buddies? (children should be paired)

2. How should children be grouped for various exhibits in order to maximize engagment (i.e., what pairs work best together)?

3. Who will be the additional adult chaperones?

4. What can be added now to the curriculum to prepare students?

5. What can I teach children about the museum prior to our visit?

6. What behavior rules can I introduce now in preparation for our visit?

7. What learning standards need to be addressed so that children will have a meaningful visit?

found to have long lasting effects. When young adults were asked to recall field trips taken during their kindergarten to twelfth grade years, visits that were remembered as primarily hands-on were more salient than those visits to museums that were less hands-on. Individuals remembered more educational information and had a more enjoyable experience on field trips that required hands-on participation compared to the field trips that did not (Pace and Tesi 2004). What children do in museums appears to have a lasting impression and therefore it is essential that teachers think critically about how to maximize the context of the museum and optimize the opportunity for young visitors to engage in play-based, experiential learning.

Play is an important aspect common to both early childhood school environments and inquiry-based, handson museum experiences. We believe that this is a key commonality that ensures successful partnerships between museums and schools. In both contexts, children gain understanding and interest when given opportunity to play. Such opportunities for individual and group play, in both environments, are essential for assuring that children will become deeply engaged in their activity (Rapp 2005). In the context of museums, both teachers and parents play a key role in encouraging play through their attunement to children's engagement and through sharing children's experiences. Play creates environments where individuals explore, manipulate, sort, and describe the phenomenon they are investigating while constructing knowledge through such experiences (Harlen 2001).

\section{Encouraging Play}

Dewey (1938) asked the question "how many students... were rendered callous to ideas, and how many lost the impetus to learn because of the way in which learning was experienced by them?" (p. 26). The answer to the question can be directly related to intrinsic motivation to learn. There is a documented decline in intrinsic motivation from third grade to seventh grade (Harter 1996). It is an unfortunate consequence of socialization and schooling that children's learning is motivated less by intrinsic interests and motivation as they progress through school. If learning becomes extrinsically motivated, students "learn" only to obtain grades, teacher approval, and to avoid criticism. Children's natural propensities to engage in autonomous learning are attenuated by the increasing structure that governs their classroom learning experiences as they progress from one grade to the next. Teachers who strive to provide developmentally appropriate contexts that afford significant learning experiences for children must be attuned to maintaining a delicate balance between structure and support for autonomy (Deci and Ryan 1982). In the preschool years, where children's learning is based on intrinsic motivation, curiosity, and a preference for challenge, children are more apt to be mastery-oriented rather than performance-driven. It is important to keep in mind that children learn by being curious about the activities engaged in by parents, teachers, and friends. In particular they are interested in those activities that parents, teachers, and friends enjoy freely (Deci and Ryan 1992). So to encourage play, parents, teachers, and friends need to be playful and join children in play. It is important that parents join children in pretend play as a way to explore the environment and try on new roles (Shine and Acosta 2000). Shine and Acosta (2000) found that, in general, parents were more concerned with what their child learned about the particular pretend play role than in the flexibility of role-playing. Such flexibility in role-playing is an integral part of social pretend play. Therefore, to encourage social pretend play, parents need to enter into pretend play and not try to guide the experience toward "real life experiences." In addition parents need to employ open-ended and person-centered questions that invite children to ask questions (Harlen 2001) so to further their exploration of the environment and their play experience. We believe that children's inquiry-based museums are an excellent context for children's informal learning and an excellent context for parents and teachers to build their responsiveness to children's natural propensity to learn through play. Children's inquiry-based museums function in structuring experiences that can be shared by children with their peers and by those that care for them and value their growth and development. 


\section{Conclusion}

Play is an integral part of development. Through play, children develop their capacities in creativity, problemsolving, logic, social knowledge, communication, selfregulation, cognitive processing and social development. The environment in which play occurs is important. The emphasis in the environment should be on the potential experiences that can occur within that particular environment. It is the educators' role to shape and support the environment in order to create environments that are conducive to quality experiences, exploration, and play. These are environments where individuals are encouraged to act on, explore, manipulate, sort, and describe the phenomena they are investigating.

Inquiry-based museums afford unique opportunities for children, parents, and teachers to explore concepts in math, science, art, music, history, and social studies. In these museums, individuals of all ages are encouraged to play because of the richness of experience that play affords. Play is intrinsically motivating. Intrinsic motivation, in turn, is an important aspect for learning and it offers new ways in which to explore the environment. Therefore, play is important for the promotion of lifelong learning and should be encouraged across individuals of all ages when visiting an inquiry-based children's museum.

\section{References}

Azmitia, M., \& Perlmutter, M. (1989). Social influences on children's cognition: State of the art and future directions. Advances in Child Development and Behavior, 22, 89-144.

Bronfenbrenner, U. (1995). Developmental ecology through space and time: A future perspective. In P. Moen, G. H. Elder, \& K. Luscher (Eds.), Examining lives in context: Perspectives on the ecology of human development (pp. 619-647). Washington, DC: American Psychological Association.

Bronfenbrenner, U. (2001). The theory of human development. In N. J. Smelser \& P. B. Baltes (Eds.), International encyclopedia of the social and behavioral sciences (Vol. 10, pp. 6963-6970). New York: Elsevier.

Bronfenbrenner, U., \& Ceci, S. J. (1994). Nature-nurture reconceptualized in developmental perspective: A bioecological model. Psychological Review, 101, 568-586.

Bronfenbrenner, U., \& Morris, P. A. (1998). The ecology of developmental processes. In W. Damon (Series Ed.), R. M. Lerner (Vol. Ed.), Handbook of child psychology (5th ed., Vol. 1, pp. 993-1028). Wiley, New York: Theoretical Models of Human Development.

Bruner, J. (1960). The process of education. Cambridge, MA: Harvard University Press.

Calabrese, N. M. (2003). Developing quality sociodramatic play for young children. Education, 123, 606-608.

Christie, J. F., \& Johnson, E. P. (1983). The role of play in socialintellectual development. Review of Educational Research, 53, 93-115.

Cole, M. (1995). The supra-individual envelope of development: Activity and practice, situation and context. In W. Damon
(Series Ed.), J. J. Goodnow, P. J. Miller, \& F. Kessel (Vol. Eds.), New directions in child development: No. 67 cultural practices as contexts for development. (pp. 105-118). San Francisco: Jossey Bass.

Cross, J. (2006). Informal learning: Rediscovering the natural pathways that inspire innovation and performance. New York: Pfeiffer Publishers.

Deci, E. L., \& Ryan, R. M. (1982). Curiosity and self-directed learning: The role of motivation in education. In L. Katz (Ed.), Current topics in early childhood education: Volume IV (pp. 7185). Norwood, NJ: Albex.

Deci, E. L., \& Ryan, R. M. (1985). Intrinsic motivation and selfdetermination in human behavior. New York: Plenum Press.

Deci, E. L., \& Ryan, R. M. (1992). The initiation and regulation of intrinsically motivated learning and achievement. In A. K. Boggiano \& T. S. Pittman (Eds.), Achievement and motivation: A social-development perspective (pp. 9-36). New York: Cambridge.

Deci, E. L., \& Ryan, R. M. (2000). The "what" and "why" of goal pursuits: Human needs and the self-determination of behavior. Psychological Inquiry, 11, 319-338.

Dempsey, J. D., \& Frost, J. L. (1993). Play environments for early childhood education. In B. Spodeck (Ed.), Handbook of research on the education of young children (pp. 306-321). New York: Macmillan Publishing.

Dewey, J. (1938). Experience and education. New York: Touchstone.

Greeno, J. G., \& Moore, J. L. (1993). Situativity and symbols: Response to Vera and Simon. Cognitive Science, 17, 49-60.

Harlen, W. (2001). Research in primary science education. Journal of Biological Education, 35(2), 61-65.

Harter, S. (1996). Teacher and classmate influences on scholastic motivation, self esteem, and level of voice in adolescents. In J. Juvoven \& K. Wentzel (Eds.), Social motivations: Understanding children's school adjustment (pp. 11-42). New York: Cambridge University Press.

Kolb, D. A. (1984). Experiential learning: Experience as the source of learning and development. Engelwood Cliffs, NJ: Prentice Hall.

Lemelin, N., \& Bencze, L. (2004). Reflection-on-action at a science and technology museum: Findings from a university-museum partnership. Canadian Journal of Science, Mathematics, andTechnology Education, 4, 467-481.

Lundmark, C. (2002). Lifelong learning. Bioscience, 52, 325

Malone, D. M. (1999). Contextual factors informing play-based program planning. International Journal of Disability, Development, \& Education, 46, 307-324.

Martin, S. S., \& Seevers, R. L. (2003). A field trip planning guide for early childhood classes. Preventing School Failure, 47, 177-180.

McLeod, J., \& Kilpatrick, K. M. (2000). Exploring science at the museum. Educational Leadership, 58, 59-63.

Pace, S., \& Tesi, R. (2004). Adult's perception of field trips taken within grades K-12: Eight case studies in the New York metropolitan area. Education, 125, 30-40.

Pellegrini, A. D., \& Boyd, B. (1993). The role of play in early childhood development and education: Issues in definition and function. In B. Spodeck (Ed.), Handbook of research on the education of young children (pp. 105-122). New York: Macmillan Publishing.

Piaget, J. (1951). Play dreams and imitation in childhood. New York: Routledge \& Kegan Paul.

Ramey-Gassert, L. (1997). Learning science beyond the classroom. The Elementary School Journal, 97, 433-450.

Rapp, W. H. (2005). Inquiry-based environment for the inclusion of students with exceptional learning needs. Remedial and Special Education, 26, 297-310.

Rogoff, B., Matusov, E., \& White, C. (1998). Models of teaching and learning: Participation in a community of learners. In D. R. 
Olson \& N. Torrance (Eds.), The handbook of education and human development: New models of learning, teaching, and schooling (pp. 388-414). Malden, MA: Blackwell.

Semper, R. J. (1990). Science museums as environments for learning. Physics Today, 43(11), 50-56.

Shine, S., \& Acosta, T. Y. (2000). Parent-child social play in a children's museum. Family Relations, 49, 45-52.

Sorrentino, R. M., \& Higgins, E. T. (Eds.). (1986). Handbook of motivation and cognition: Foundations of social behavior. New York: Guilford.

Speaker, K. M. (2001). Interactive exhibits theory: Hints for implementing learner-centered activities in elementary classrooms. Education, 121, 610-614.

Stams, F. J. M., Juffer, F., \& van Ijzenzoorn, M. H. (2002). Maternal sensitivity, infant attachment, and temperament in early childhood predict adjustment in middle childhood: The case of adopted children and their biologically unrelated parents. Developmental Psychology, 38, 806-821.

Vygotsky, L. S. (1966). Play and its role in the mental development of the child. Soviet Psychology, 12(6), 62-76, (Original work published 1933).

Vygotsky, L. S. (1978). Mind in society: The development of higher mental processes In M. Cole, V. John-Steiner, S. Scribner, \& E. Souberman (Eds.). Cambridge, MA: Harvard University Press (Original work published 1930, 1933, 1935).

Vygotsky, L. S. (1987). Thinking and speech. In N. Minick (Trans.). R. W. Rieber \& A. S. Carton (Eds.). The collected works of L. S. Vygotsky: Vol. 1. Problems of general psychology (pp. 37-285). New York: Plenum (Original work published 1934).

Xanthoudaki, M. (1998). Is it always worth the trip? The contribution of museum and gallery educational programmes to classroom art education. Cambridge Journal of Education, 28, 181-196. 
Copyright of Early Childhood Education Journal is the property of Springer Science \& Business Media B.V. and its content may not be copied or emailed to multiple sites or posted to a listserv without the copyright holder's express written permission. However, users may print, download, or email articles for individual use. 